\title{
Mechanical and Thermomechanical Properties of Clay-Cowpea (Vigna Unguiculata Walp.) Husks Polyester Bio-Composite for Building Applications
}

\author{
Esther Nneka Anosike-Francis ${ }^{1, *(\mathbb{D}}$, Paschal Ateb Ubi ${ }^{2}$, Ifeyinwa Ijeoma Obianyo ${ }^{1}$, \\ Godwin Mong Kalu-Uka ${ }^{1,3} \mathbb{D}^{\mathbb{D}}$, Abdulhakeem Bello ${ }^{1,4}$, Michael Ikpi Ofem ${ }^{5}$, Abel Olajide Olorunnisola ${ }^{6} \mathbb{D}$ \\ and Azikiwe Peter Onwualu ${ }^{1}$ (D)
}

Citation: Anosike-Francis, E.N.;

Ubi, P.A.; Obianyo, I.I.;

Kalu-Uka, G.M.; Bello, A.; Ofem, M.I.;

Olorunnisola, A.O.; Onwualu, A.P.

Mechanical and Thermomechanical

Properties of Clay-Cowpea (Vigna

Unguiculata Walp.) Husks Polyester

Bio-Composite for Building

Applications. Appl. Sci. 2022, 12, 713.

https://doi.org/10.3390/

app12020713

Academic Editor: Asterios Bakolas

Received: 29 November 2021

Accepted: 24 December 2021

Published: 12 January 2022

Publisher's Note: MDPI stays neutral with regard to jurisdictional claims in published maps and institutional affiliations.

Copyright: (C) 2022 by the authors. Licensee MDPI, Basel, Switzerland. This article is an open access article distributed under the terms and conditions of the Creative Commons Attribution (CC BY) license (https:// creativecommons.org/licenses/by/ $4.0 /)$.
1 Department of Material Science and Engineering, African University of Science and Technology (AUST), Km 10 Airport Road, Galadimawa Roundabout, Abuja 900109, Nigeria; iobianyo@aust.edu.ng (I.I.O.); gkaluuka@aust.edu.ng (G.M.K.-U.); abello@aust.edu.ng (A.B.); aonwualu@aust.edu.ng (A.P.O.)

2 Department of Mechanical Engineering, University of Calabar, Calabar 540004, Nigeria; paschalubi@unical.edu.ng

3 Department of Mechanical/Mechatronic Engineering, Alex Ekwueme Federal University, Ndufu-Alike 480213, Nigeria

4 Department of Theoretical and Applied Physics, African University of Science and Technology (AUST), Km 10 Airport Road, Galadimawa Roundabout, Abuja 900109, Nigeria

5 Department of Mechanical Engineering, Cross River University of Technology, Calabar 540252, Nigeria; michaeliofem@crutech.edu.ng

6 Department of Wood Products Engineering, University of Ibadan, Ibadan 200132, Nigeria; abelolorunnisola@yahoo.com

* Correspondence: eanosike@aust.edu.ng

\begin{abstract}
This study investigates the feasibility of creating a clay polymer-based composite using cowpea husk $(\mathrm{CPH})$ as filler for production of roof tiles. Polymeric composites were fabricated by mixing unsaturated polyester (UPT) resin with cowpea husk at different filler weights and curing. A hybrid composite was produced with the addition of $3 \mathrm{wt} . \%$ clay and all samples produced were subjected to flexural, hardness and dynamic mechanical analysis (DMA) tests. The effect of clay addition on the mechanical and thermo-mechanical behaviour of formulated composites was investigated. The morphological analysis of the mono and hybrid system shows a rough and coarse inhomogeneous surface with voids created due to the addition of $\mathrm{CPH}$ filler for the mono reinforced and clay uniformly filling the voids that were created by the $\mathrm{CPH}$ in the hybrid composite. It is observed that hardness, tensile modulus and flexural modulus of hybrid composites increase with an increase in the $\mathrm{CPH}$ contents, while the strength and flexural strength all decrease with filler content. The optimal composition was obtained using Grey relational analysis (GRA) at 18\% CPH for both mono and hybrid composite. The results imply that the composite combination can be used in making rooftiles and/or also in applications where low strength is required.
\end{abstract}

Keywords: bio-composites; biomass valorisation; clay; cowpea husk; hybrid composite; mechanical properties; polyester; roofing tiles

\section{Introduction}

The availability of affordable and functional housing is one of the basic human needs that is vital to the wellbeing of every human. The quality of the housing portrays a person's standard of living and socio-economic status in the society. Even though housing is a necessity, its provision has been grossly inadequate especially in developing countries such as Nigeria [1]. According to the Federal Mortgage Bank of Nigeria (FMBN), the housing deficit in Nigeria is estimated to be between 17 to 20 million units [2], far ahead of other African countries, such as Kenya, South Africa and Ethiopia, 
which have shortages of 2, 2.5 and 1.2 million units, respectively [3]. Experts believe that only about 10 percent of people who desire to own a home in Nigeria can afford it, compared to $72 \%$ in the United States of America, 78\% in the United Kingdom and 60\% in China [3]. Sufficient and adequate housing has been linked to good mental health and a defence to the spread of diseases, such as COVID-19 [4,5]. The real estate sector plays an important role in developing economies, such as Nigeria, by creating jobs especially for unskilled labour [6] and accounting for 6.36 per cent of the nation's Gross Domestic Product (GDP) in 2019 [2].

The escalating cost of construction materials and dependence on imported building materials have been top on the list of constraints towards provision of adequate housing [7]. One of the ways to tackle this problem is by promoting the development and utilisation of sustainable low-cost materials through usage of earth-based materials (clay), agro-wastes and polymers [8-15]. Research efforts in the use of earth-based materials, agro-wastes and polymers are used to drive the current global shift towards a circular economy where materials are utilised and reused with no waste $[16,17]$. In such production systems, materials which ordinarily will be discarded as waste are converted to useful materials [18,19]. One of the sustainable ways to bring down the cost of building materials, contribute towards affordable housing in Africa and ensure environmental sustainability is to apply this concept of circular economy in developing new composite materials from waste to support the building industry $[20,21]$.

Around the world, burning of agro waste has been the most common means of disposal [22]. The on-field impact of this activity includes removal of a large portion of the organic material hence, adversely hampering the cultivation of the next crop [23]. While the off-field effect of this action is degradation of air quality resulting in aggravation of respiratory problems, poor visibility and skin diseases due to the creation of excess carbon in the atmosphere $[24,25]$. This has created the need for agro waste valorisation to help reduce environmental impact and decrease raw materials cost.

Small volume fraction of agro fibres has been used in production of ceiling tiles [26], roofing sheets [27] and panels [28]. Cement-based roofing tiles with up to $15 \%$ replacement with coir fibre were produced by Darsana et al. [29] and demonstrated to be a quality roofing material and considerably cheaper when compared to the ordinary cement concrete tile. A study by Pasilo and Teeboonma [30] looked into the properties of roofing tiles produced from agricultural residues such as corn cob, palm fruit bunch and water hyacinth resulted in roof tiles with properties similar to commercially produced ones. The use of expanded polystyrene (EPS) as an alternative to roofing technology was studied by Topacio et al. [31] who demonstrated that it is conceivable to manufacture a roof tile using waste EPS plastic as a substitute for cement.

Recent advancements in the use of reinforced composites in structural applications have been reported by Okafor and Ihueze [32], Beaumont et al. [33], Pei et al. [34] and Atiqah et al. [35]. The mechanical behaviour, physical and thermo-mechanical properties of reinforced composites have been studied by several researchers [36-39] to determine their technical and economic feasibility. Several studies have also considered various modifications in terms of treatment, method of production and weight fraction variations of these composites for better properties [40-43]. One of such modifications is the addition of clay at macro and nano levels, and the effects of clay addition to bio-composites have been studied by many researchers. For example, Arulmurugan and Venkateshwara [44] investigated the influence of alkali treatment and addition of $5 \%$ weight montmorillonite nanoclay as filler on mechanical and visco-elastic behaviour of jute fibre polymer composite. The produced composites showed both improved mechanical properties and an increase in the glass transition temperature from 109 to $115^{\circ} \mathrm{C}$. Hossen et al. [45] studied the effect of fibre treatment and nanoclay on the tensile properties of jute fibre-reinforced polyethylene/clay nanocomposites and showed the addition of a small amount of nanoclay improved the tensile properties of the 
composite without compromising the weight of the composite. Okonkwo et al. [46] evaluated the feasibility of enhancing the properties of Bambara nut shell particulate reinforced polyester composite by incorporation of clay and the composite showed higher mechanical properties than existing composites.

However, to the best of our knowledge, there is no published report or investigation showing the incorporation of $\mathrm{CPH}$ which is a biomass resources and $3 \%$ clay as a filler in an UPT composite. With the abundance of biomass waste and menace of polymer waste in Africa [32,47], it is important to valorise and find alternative economic uses for them, while contributing to cleaning the environment. Thus, this paper presents the experimental investigations towards developing a composite with $\mathrm{CPH}$ in an unsaturated polyester matrix for sustainable building application. The effect of clay addition on the mechanical and thermo-mechanical behaviour of the formulated composites was investigated for possible application in roofing tiles. Scanning electron microscope (SEM) was used for the morphological analysis of the mono and hybrid system. This was used to view the dispersion of both $\mathrm{CPH}$ and clay in the UPT composite.

\section{Materials and Methods}

\subsection{Materials}

Cowpea husks $(\mathrm{CPH})$ were collected from a farm in Nassarawa State, North central, Nigeria right after cowpea harvest. They were first cleaned of dust and dirt and sun dried for $24 \mathrm{~h}$. They were crushed in an electric grinder and classified in a horizontal screen shaker of different sizes. The particles that remained in the $45 \mu \mathrm{m}$ sieves were used for the composite production. Clay was obtained from Galadimawa area in Federal Capital Territory; Abuja, Nigeria with a Global Positioning System (GPS) coordinates of $9^{\circ} 4^{\prime} 0.0012^{\prime \prime} \mathrm{N}$ and $7^{\circ} 28^{\prime} 59.9988^{\prime \prime} \mathrm{E}$ at $491 \mathrm{~m}$ above sea level. The clay used in this study has been previously characterised in an earlier work by Ngayakamo et al. [14], where it was shown that the mineral composition is dominated by kaolinite $\left(\mathrm{Al}_{2} \mathrm{Si}_{2} \mathrm{O}_{5}(\mathrm{OH})_{4}\right)$, muscovite $(\mathrm{KF})_{2}\left(\mathrm{Al}_{2} \mathrm{O}_{3}\right)_{3}\left(\mathrm{SiO}_{2}\right)_{6}$, phengite $\left(\mathrm{K}(\mathrm{AlMg})_{2}(\mathrm{OH})_{2}(\mathrm{SiAl})_{10} \mathrm{O}_{10}\right)$ group of micas and haematite $\left(\mathrm{Fe}_{2} \mathrm{O}_{3}\right)$. While the chemical composition of the clay soil mainly consists of $66.10-67.12 \%$ silica $\left(\mathrm{SiO}_{2}\right)$ and alumina $\left(\mathrm{Al}_{2} \mathrm{O}_{3}\right)$ between $14.93-19.45$. The mined clay lumps were pulverized, milled, sieved and soaked in water to remove impurities such as stones and decaying organic matter. The mixture was then rinsed severally with distilled water. The obtained clay particles were sun dried for $24 \mathrm{~h}$ before drying in a laboratory oven at a temperature of $90^{\circ} \mathrm{C}$ for $4 \mathrm{~h}$. Natural clay powder of $<45 \mu \mathrm{m}$ was used to produce the composite samples.

Unsaturated polyester resin with the cobalt naphthenate (accelerator) and methyl ethyl ketone peroxide (MEKP) (catalyst) was obtained from a local vendor in Kaduna state, Nigeria. The choice of UPT resin is due to its easy handling, low cost, good physical and mechanical properties, high transparency, fast curing at room temperature with no gas generation and also because the individual polymer chains of the UPT cross-links during curing, it can be cast and laminated at a temperature and pressure lower than other thermosetting resin [48].

\subsection{Composite Preparation and Experimental Design}

The graphical description of the research method is shown in Figure 1.

In the production of the composites, $2 \mathrm{~mL}$ catalyst and $1 \mathrm{~mL}$ accelerator were utilized for each $100 \mathrm{~g}$ of polyester resin. The choice of $1 \mathrm{~mL}$ accelerator is to avoid a sudden reaction which could affect composite mechanical properties. The measured quantity of $\mathrm{CPH}$ was mixed with the UPT at room temperature and stirred continuously for $3 \mathrm{~min}$ after which MEKP was added using a syringe and stirred continuously for another $2 \mathrm{~min}$ to obtain a homogenous mix. The accelerator was added and stirred for another $1 \mathrm{~min}$ before pouring the mix in a mould of dimension $180 \times 160 \times 5 \mathrm{~mm}$ smeared with a releasing agent for easy removal of composite (Figure 1). The composite was left to cure at room 
temperature for $24 \mathrm{~h}$ as shown in Figure 1 before demoulding and manually cutting off overflow flakes. This was repeated for varying weight fractions of cowpea husk particles which ranged from $10 \%$ and so on. A hybrid composite of $3 \mathrm{wt} . \%$ clay and varying weight fraction of $\mathrm{CPH}$ was produced to check the effect of clay addition on the CPH/UPT. Sample description and composition for the production of the particle boards are shown in Table 1. The amount of clay particles used was fixed at $3 \mathrm{wt} . \%$ in line with previous works from the literature [46]. An unreinforced UPT sample was fabricated to serve as control for comparison in studying the effect of the $\mathrm{CPH}$ reinforcement.

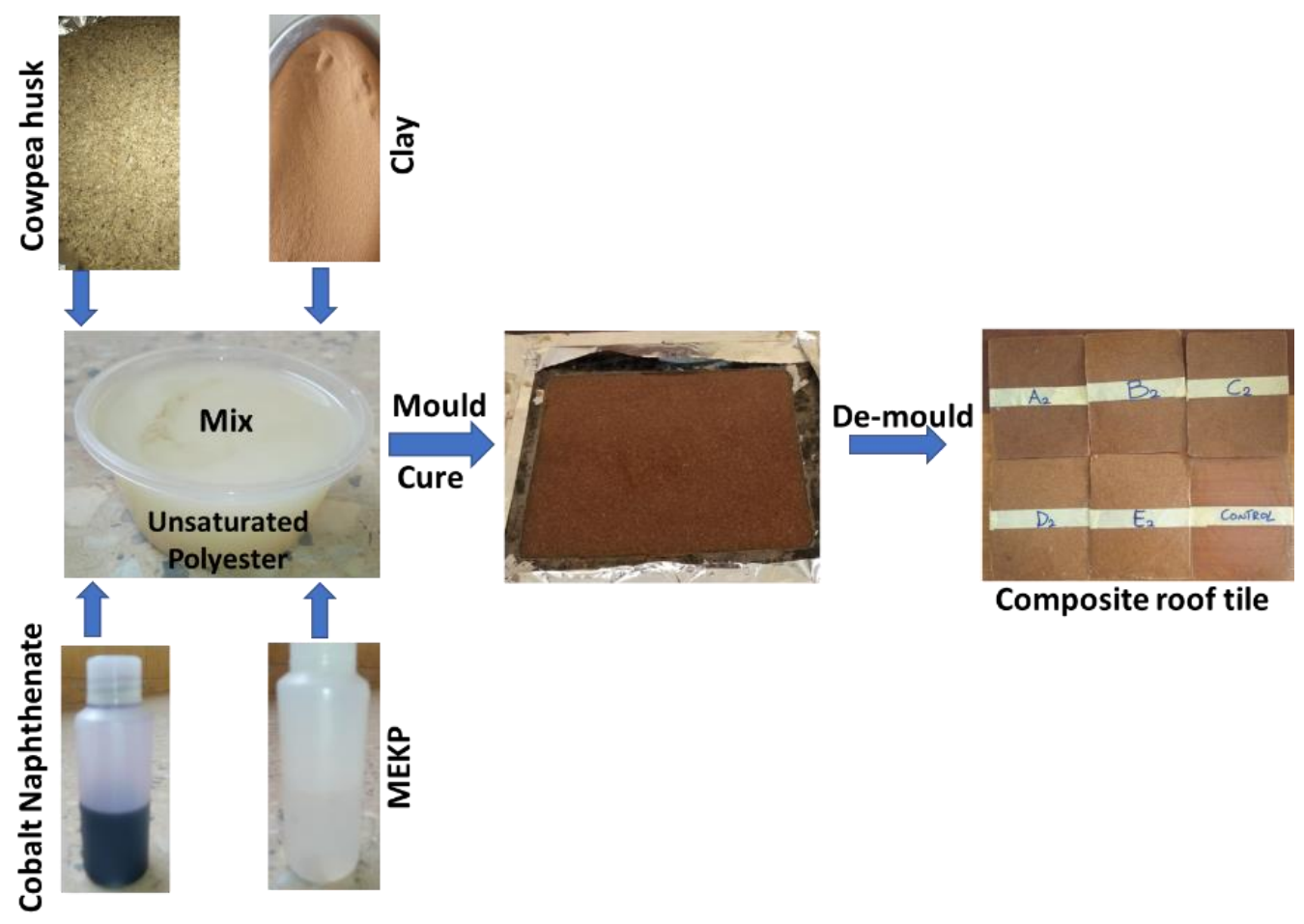

Figure 1. Graphical description of the research method.

Table 1. Experimental design of composite.

\begin{tabular}{ccccc}
\hline \multirow{2}{*}{ Samples } & \multirow{2}{*}{ Designation } & \multicolumn{3}{c}{ Composition (wt.\%) } \\
\cline { 3 - 5 } & & Polyester & Clay & CPH \\
\hline $100 \%$ UPT & Control & 100 & 0 & 0 \\
$10 \%$ CPH & A1 & 90 & 0 & 10 \\
$12 \%$ CPH & A2 & 88 & 0 & 12 \\
$14 \%$ CPH & B1 & 86 & 0 & 14 \\
$16 \%$ CPH & B2 & 84 & 0 & 16 \\
$18 \%$ CPH & C1 & 82 & 0 & 18 \\
$10 \%$ CPH + 3\% clay & C2 & 87 & 3 & 10 \\
$12 \%$ CPH + 3\% clay & D1 & 85 & 3 & 12 \\
$14 \%$ CPH + 3\% clay & D2 & 83 & 3 & 14 \\
$16 \%$ CPH + 3\% clay & E1 & 81 & 3 & 16 \\
$18 \%$ CPH + 3\% clay & E2 & 79 & 3 & 18 \\
\hline
\end{tabular}

Mechanical behaviour of the composites was analysed by carrying out tensile, flexural, and hardness test. These properties of particulate reinforced polymers are dependent on factors such as weight fraction, extent of distribution, particle size, interfacial adhesion, presence of agglomerates, and voids among others. 


\subsection{Morphology and Mechanical Behaviour of the Composite \\ 2.3.1. Morphological Examination}

The morphology and microstructure of the samples was examined using a Carl Zeiss SEM (Model: evo10LS-EDAX, made in Germany) scanning electron microscope. Samples were coated with thin layer gold nanoparticles in a mini sputter coater (Model: Quorum SC 7620, made in UK) prior to characterization to prevent the samples from charging and reflection.

\subsubsection{Tensile Test}

Tensile behaviour of the composite samples was conducted in accordance with ASTM D3039 [49] standard. Samples were machined to a rectangular shape of dimension of $100 \times 20 \times 5 \mathrm{~mm}$ while a Tensometric machine M500-25CT using a crosshead speed of $50 \mathrm{~mm} / \mathrm{min}$ was used to conduct the test. Gauge length of the samples is $40 \mathrm{~mm}$. Three samples were tested and average values taken.

\subsubsection{Flexural Test}

Bending behaviour of the produced samples was determined via 3-point flexural test in accordance with ASTM D790 [50] standard using a $100 \mathrm{KN}$ capacity Universal Materials Testing machine, Cat.Nr.261. Rectangular samples of dimension $80 \times 30 \times 5 \mathrm{~mm}$ were used for the test. Span length of the samples during the test is $100 \mathrm{~mm}$. In a three-point bending test, the maximum bending stress used to break a beam refers to the flexural strength of a material whereas the ratio of stress and strain in a materials' linear elastic region refers to the flexural modulus [51].

\subsubsection{Hardness Test}

Hardness of the composite samples was determined with an FIE Vickers Hardness Tester model MV1-PC serial no 07/2012-1329. Hardness is the ability of a material to resist indentation under load and a fixed speed. Three samples each were tested for each group for all the mechanical testing specimen.

\subsubsection{Thermomechanical Analysis}

Thermomechanical analysis of the composite samples was conducted using a NETZSCH DMA 242 analyser to determine the visco-elastic properties of the samples. The test was carried out from $27^{\circ} \mathrm{C}$ to $150^{\circ} \mathrm{C}$ using a heating rate of $3 \mathrm{~K} / \mathrm{min}$, amplitude of $50 \mu \mathrm{m}$ and frequency of $5 \mathrm{~Hz}$ according to ASTM D5023-15 [52] standard using samples of $40 \mathrm{~mm}$ span length, $12 \mathrm{~mm}$ width and actual specimen thickness. Visco-elastic behaviour of formed composite samples under stress and over a wide range of temperature was studied by dynamic mechanical analysis (DMA). The DMA studies of the composite is important since the materials usually undergo heterogeneous types of dynamic stretch during service life. Using the DMA, it is feasible to determine the mechanical performance of the final product using the loss modulus ( $\left.E^{\prime \prime}\right)$, storage modulus $\left(E^{\prime}\right)$, and damping factor $(\tan \delta)$. The loss modulus is linked with the viscous response of the polymeric structure and indicates the released energy in terms of heat. The rigidity and stiffness of a polymeric structure are measured using the storage modulus. Tan $\delta$ or mechanical damping factor is the ratio of loss and storage modulus.

\subsubsection{Statistical Analysis of Responses}

Experimental values obtained from the mechanical tests were analysed for signal to noise $(\mathrm{S} / \mathrm{N})$ ratio with the aim of achieving optimization of individual responses. The $\mathrm{S} / \mathrm{N}$ ratio values were calculated using larger-the better characteristics from Equation (1) and shown in Tables 2 and 3 for both mono-reinforced and hybrid composites. Further optimization of the values was carried out using Grey relational analysis (GRA) to determine the optimum combination in property of the fabricated composites. GRA is part of grey system theory, that was proposed by Deng in 1982 [53] and is used 
for solving problems with complicated interrelationships amid multiple factors and variables [54]. According to Yiyo et al. [55], this procedure involves utilizing the S/N ratio values obtained to calculate the Grey relational generation (GRG) using the largerthe better attributes with Equation (2) followed by Grey relation coefficient (GRC) using Equation (3) [55] and afterwards Grey relational grade (GR*grade) using Equation (4) [55]. The GRG is the step in GRA that converts the original data into a sequence that can be compared, while GRC is used to identify the elements that influence the system's behaviour. The concluding process of GRA is the determination of optimal factors for the single response by the $\mathrm{GR}^{*}$ grade.

$$
\text { Larger - the better : } \frac{S}{N}=-10 \log \frac{1}{n}\left(\sum_{i=1}^{n} \frac{1}{y^{2}}\right)
$$

where $y=$ number of observations, $n=$ response value.

Table 2. Experimental result of the $\mathrm{S} / \mathrm{N}$ ratio values for mono-reinforced composites.

\begin{tabular}{ccccccc}
\hline Run & $\begin{array}{c}\text { S/N for } \\
\mathbf{w t} \% \text { UPT }\end{array}$ & $\begin{array}{c}\text { S/N for } \\
\text { Flexural } \\
\text { Strength } \\
\mathbf{( M P a )}\end{array}$ & $\begin{array}{c}\text { S/N for } \\
\text { Flexural } \\
\text { Modulus } \\
\mathbf{( G P a )}\end{array}$ & $\begin{array}{c}\text { S/N for } \\
\text { Tensile } \\
\text { Strength } \\
\mathbf{( M P a )}\end{array}$ & $\begin{array}{c}\text { S/N for } \\
\text { Tensile } \\
\text { Modulus } \\
\mathbf{( G P a )}\end{array}$ & $\begin{array}{c}\text { S/N for } \\
\text { Hardness } \\
\text { (HV) }\end{array}$ \\
\hline A1 & 39.0849 & 28.0830 & 8.5821 & 23.9373 & 0.6120 & 32.1491 \\
A2 & 38.8897 & 26.7612 & 7.6655 & 20.0563 & 4.1095 & 33.2797 \\
B1 & 38.6900 & 26.8957 & 7.4251 & 19.5224 & 3.5738 & 34.1292 \\
B2 & 38.4856 & 27.8820 & 5.9025 & 20.8279 & 2.5551 & 34.3866 \\
C1 & 38.2763 & 25.0861 & 3.5853 & 21.0884 & 1.8052 & 34.9436 \\
\hline
\end{tabular}

Table 3. Experimental result of the $\mathrm{S} / \mathrm{N}$ ratio values for hybrid composites.

\begin{tabular}{ccccccc}
\hline Run & $\begin{array}{c}\text { S/N for } \\
\text { wt\% UPT }\end{array}$ & $\begin{array}{c}\text { S/N for } \\
\text { Flexural } \\
\text { Strength } \\
\mathbf{( M P a )}\end{array}$ & $\begin{array}{c}\text { S/N for } \\
\text { Flexural } \\
\text { Modulus } \\
\mathbf{( G P a )}\end{array}$ & $\begin{array}{c}\text { S/N for } \\
\text { Tensile } \\
\text { Strength } \\
\mathbf{( M P a )}\end{array}$ & $\begin{array}{c}\text { S/N for } \\
\text { Tensile } \\
\text { Modulus } \\
\text { (GPa) }\end{array}$ & $\begin{array}{c}\text { S/N for } \\
\text { Hardness } \\
(\mathbf{H V )}\end{array}$ \\
\hline C2 & 38.7904 & 18.3291 & 8.0864 & 24.6701 & 9.8914 & 32.1491 \\
D1 & 38.5884 & 17.8530 & 6.3613 & 21.9729 & 9.2510 & 33.2797 \\
D2 & 38.3816 & 10.9555 & 5.2490 & 19.1808 & 9.2838 & 34.1292 \\
E1 & 38.1697 & 5.4368 & 4.5577 & 13.0449 & 7.9588 & 34.3866 \\
E2 & 37.9525 & 1.0616 & -2.6154 & 12.1919 & 5.9771 & 34.9436 \\
\hline
\end{tabular}

$$
\text { Larger - the better attributes }\left(\chi_{i j}\right)=\frac{y_{i j}-\underline{y}_{i}}{\bar{y}_{i}-y_{j}}
$$

$(i=1,2,3,4 \ldots \ldots m$ and $j=1,2,3,4 \ldots n)$ where, $y_{i}=\left(y_{i 1}, y_{i 2}, \ldots, y_{i j}, \ldots, y_{i n}\right), y_{i j}$ is the performance value of attribute $j$ of alternative $i$ and $\bar{y}_{i}=\max \left\{y_{i j}, i=1,2, \ldots, m\right\}$ and $\underline{y}_{i}=\min \left\{y_{i j}, i=1,2, \ldots, m\right\}$.

$$
\gamma\left(\chi_{0 j}, \chi_{i j}\right)=\frac{\Delta_{\min }+\beta \Delta_{\max }}{\Delta_{i j}+\beta \Delta_{\max }} \quad(i=1,2, \ldots, \text { m and } j=1,2, \ldots, n)
$$

where, $\gamma\left(x_{0 j}, x_{i j}\right)$ is the GRC between $x_{i j}$ and $x_{0 j}$.

$\Delta_{i j}=x_{0 j}-x_{i j}, \Delta_{\text {min }}=\min \left(\Delta_{i j}, i=1,2, \ldots, m ; j=1,2, \ldots, n\right), \Delta_{\max }=\max \left(\Delta_{i j}, i=1,2, \ldots, m ;\right.$ $j=1,2, \ldots, n)$ and $\beta$ is the distinguishing coefficient, $\beta \in[0,1]$. The aim of the distinguishing coefficient $(\beta)$ is to compress or expand the range of the grey relational coefficient and 0.5 is the broadly accepted value [56]. 


$$
G R * \text { grade }=\frac{\text { individual } G R C}{\text { number of experimental responses }}
$$

\section{Results and Discussion}

\subsection{Morphological Analysis}

SEM micrographs of three representative samples are shown in Figure 2. The representative micrographs were chosen due to the fact that all samples of the various groups (neat UPT, mono reinforced and hybrid composites) show similar morphology. Figure 2a shows the SEM image of the pure unsaturated polyester resin surface which is smooth and neat indicating a strong interconnectivity without revealing any microscopic separation. Figure $2 \mathrm{~b}$ shows a rough and coarse inhomogeneous surface with voids created due to the addition of $\mathrm{CPH}$ filler. These voids are attributed to inhomogeneous dispersion of the $\mathrm{CPH}$ in the UPT matrix. The presence of the voids could lead to cracks and eventually premature fracture leading to poor mechanical performance of the composite. Figure $2 \mathrm{c}$ shows the SEM image of the hybrid composite. This was carried out to study its effect in the composite. From the figure, it was observed that the clay uniformly fills the voids that were created by the $\mathrm{CPH}$ biomass. This could be beneficial to the modulus and hardness properties of the composite.
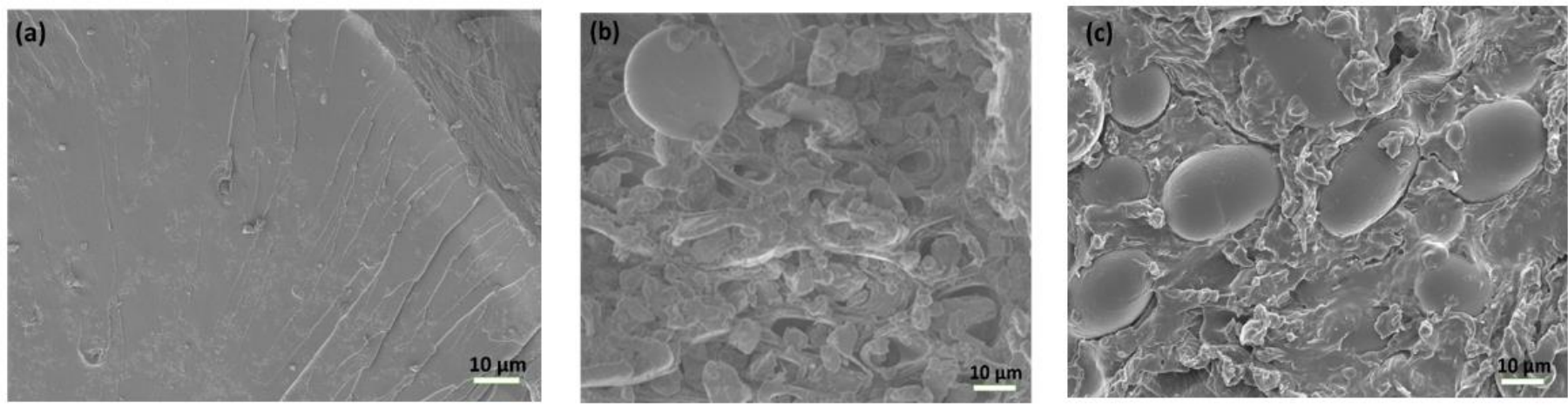

Figure 2. Scanning electron micrographs of (a) unsaturated polyester resin (UPT) (b) a representative mono reinforced composite $(\mathbf{c})$ representative of hybrid composite.

\subsection{Mechanical Properties}

\subsubsection{Tensile Properties}

The effects of $\mathrm{CPH}$ addition on the tensile strength and modulus of the composites are shown in Figure 3a. UPT resin showed a tensile strength of $29 \mathrm{MPa}$. It can be seen that as the $\mathrm{CPH}$ content was introduced at $10 \%$, the tensile strength of the unsaturated polyester composites decreased. Further reduction was noticed with an increment in filler content until it reached $9.465 \mathrm{MPa}$ at 14 weight percent $\mathrm{CPH}$. Similar decrease in UPT strength with addition of filler has been reported by Mourad et al. [57]. The particle size of the $\mathrm{CPH}$ could play a critical role in the reduction of the tensile strength by increasing the area of stress concentration zones [58]. Furthermore, the lower tensile strength at higher $\mathrm{CPH}$ content may be due to formation of agglomeration of $\mathrm{CPH}$ particulates leading to poor crosslinking of polyester chains. Although the tensile strength decreased with increasing filler content, the produced composites showed favourable results $(9.465-15.735 \mathrm{MPa})$ that may be similar or higher in some cases when compared to published reports on some construction materials. For example, Adi et al. [59] reported $4.23 \mathrm{MPa}$ for $60 \%$ weight bauxite residue while foam glass, mineral fibres and polystyrene reported $0.689,0.069$, and $0.310 \mathrm{MPa}$, respectively. More so, the obtained tensile strength values are higher than the values reported by Abu-Jdayil et al. [60] of 4.35 and 1.25 MPa for fine and coarse crumb rubber polyester composites, respectively. However, for the tensile modulus, $10 \%$ initial inclusion of $\mathrm{CPH}$ resulted 
in a slight drop in the modulus value of the composite. The maximum tensile modulus obtained is $1.605 \mathrm{GPa}$, i.e., $12 \% \mathrm{CPH}$ content and $88 \%$ polyester. Beyond that, the tensile modulus ranges from between 1.509 to $1.231 \mathrm{GPa}$. This drop in tensile modulus is probably due to an increase in filler content, which results in poor load transmission between the fibres. In addition, high fibre concentrations imply resin-depleted areas, resulting in insufficient fibre-matrix adhesion for stress transfer [61]. The addition of clay further reduced the tensile strength by over $47.57 \%$ while increasing the tensile modulus by $136.44 \%$ as shown in Figure $3 \mathrm{~b}$. The reduction in tensile strength could be due to agglomeration in the hybrid resulting in non-uniform stress transfer while the increase in the modulus could be due to the absence of voids or pores and good interfacial bonding [62]. This is similar to the observation of Fan et al. [63] who reported reduction in tensile strength and improvement in tensile modulus with addition of clay in claypolypropylene nanocomposite.
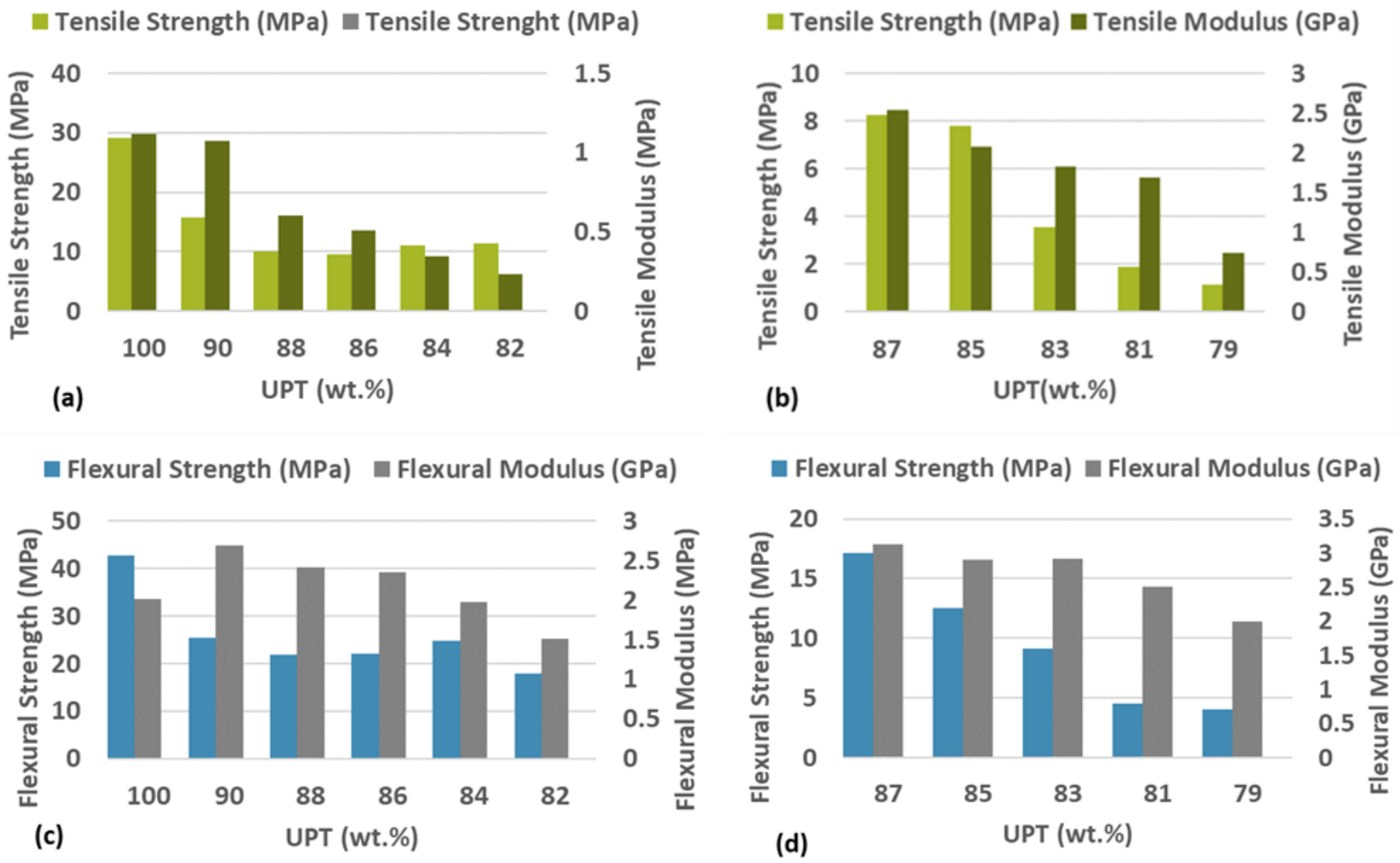

Figure 3. (a) Tensile properties (b) Tensile properties hybrid composite (c) Flexural properties (d) Flexural properties of hybrid composite.

\subsubsection{Flexural Properties}

Figure $3 \mathrm{c}$ illustrates the flexural behaviour of the cowpea husk reinforced composites. Flexural strength and flexural modulus peaked at $10 \mathrm{wt} . \%$ reinforcement with a value of $25.36 \mathrm{MPa}$ and $2.686 \mathrm{GPa}$ respectively. It can be seen that initial $10 \%$ inclusion of cowpea husk to polyester resin reduced the flexural strength of composites by $32.49 \%$, while increasing its flexural modulus by $16.27 \%$. This behaviour was also observed by Adi et al. [59] in addition of seawater-neutralized bauxite residue in unsaturated polyester and Norizan et al. [64] with sugar palm yarn fibre reinforced unsaturated polyester composite. $\mathrm{CPH}$ addition seems to encourage crack propagation thereby reducing composite toughness which results in lower values of flexural strength [65]. In addition, the increase in stiffness compared to the unreinforced polyester was observed, and it is due to the presence of strong interfacial adhesion between the cowpea husk 
particles and UPT matrix [66]. Sufficient amount of cowpea husk in the UPT matrix facilitates effective stress transfer within the matrix due to intrinsic properties of cowpea husk [67].

Beyond a $16 \%$ addition of the cowpea husk, there is a reduction in interfacial distance leading to a decrease in chain mobility and total surface for fibre matrix interaction. Hence a decline in flexural property of the UPT composite probably due to formation of agglomerates at higher filler concentration causing insufficient stress transfer between fibres and the matrix as observed by Okonkwo et al. [46] for Bambara nut shell polyester composite, for chicken feather [68] and for coconut and snail shell polyester composites [36]. The incorporation of clay (Figure 3d) improved the flexural modulus property of the hybrid composite with sample D2 containing $16 \%$ fibre and $83 \%$ UPT recording the maximum flexural modulus value of $2.912 \mathrm{GPa}$ and sample E2 with $18 \%$ fibre having the minimum at $1.99 \mathrm{GPa}$.

The enhancement of flexural modulus can be explained by the relatively higher aspect ratio of the clay, which can fill the holes between the reinforcing fibre matrix, $[38,66,69]$ thus, decreasing the void content as the weak point of the composite material. Chee S.S et al. [38] observed a similar trend in increase in flexural property by adding $1 \%$ nanoclay in a hybrid composite. However, there was a decrease in flexural strength upon addition of clay and this can be linked to the formation of agglomerates which creates stress concentration points leading to early failure of the composites. Similar results have been observed by Mourad et al. [57] and Abu-Jdayil et al. [60].

\subsubsection{Hardness}

The Vicker's hardness results obtained for the samples are shown in Figure 4a,b. There is a continuous increase in hardness with an increase in cowpea husk fibre content. Expansion in hardness of composites might be ascribed to the solidifying impact of the filler particles as composites become stiffer and thus harder as reinforcement increases, as shown in Figure 3 [70]. This is consistent with previous studies [37,71,72]. All the composites recorded hardness values higher than the $100 \%$ unsaturated polyester similar to the works of Ala, et al. [73] and Kaymakci et al. [74] Addition of 3\% clay into the composite increased the Vicker's hardness values of all the sample because clay enhanced the interfacial adhesion between the unsaturated polyester and $\mathrm{CPH}$; therefore, prompting less micro-voids and filler-polyester debonding in the interphase region [20,75]. The maximum hardness value of 55.87 and $69.7 \mathrm{HV}$ at $18 \% \mathrm{CPH}$ composition was exhibited by mono-reinforced and hybrid composites, respectively.
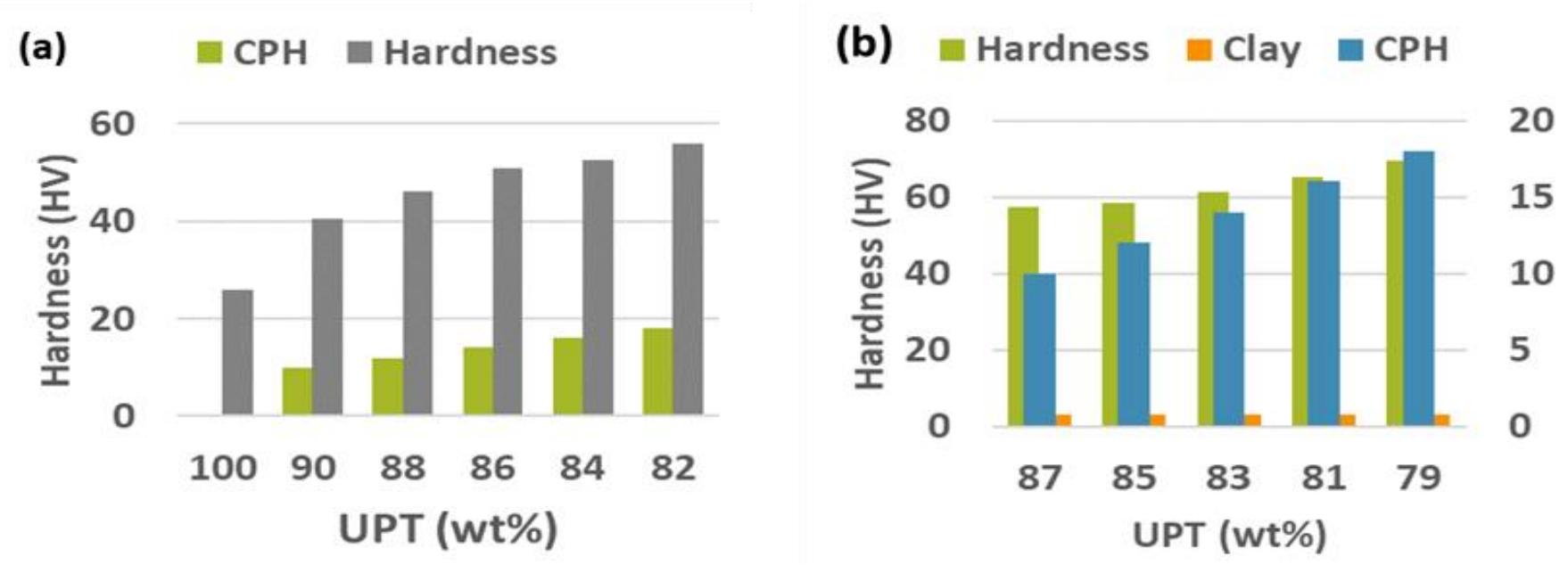

Figure 4. (a) Graph of wt\% of mono-reinforced and (b) hybrid composite against hardness. 


\subsection{Thermomechanical Properties}

\subsubsection{Storage Modulus ( $\left.E^{\prime}\right)$}

Figure 5a shows the storage modulus variation as a function of temperature for the investigated composites. Storage modulus is a measurement of the material's stiffness. In all the composites studied, loss in stiffness is observed with an increase in temperature due to increased particle mobility leading to a decrease in storage modulus. Sample A2 containing $12 \% \mathrm{CPH}$ and $88 \%$ UPT resin exhibited the highest storage modulus of $2393.39 \mathrm{MPa}$ at $28.2{ }^{\circ} \mathrm{C}$ while the lowest was obtained for A1 $1879.02 \mathrm{MPa}$ of $10 \% \mathrm{CPH}$ and $90 \%$ UPT resin at similar temperature reading which corresponds to the elastic modulus values in Figure 3a. This implies that $12 \% \mathrm{CPH}$ is the optimum amount of $\mathrm{CPH}$ to obtain enhanced modulus. This is also similar to the result of fly ash hybrid polyester composite [76] and clay-jute fibre polymer composite [77]. The effect of hybridization with 3\% clay on the storage modulus was investigated as presented in Figure 5d. Addition of 3\% to the various mix (Figure $5 \mathrm{~d}$ ) led to an increase in modulus for sample C2 which has a mixture of $87 \%$ UPT and $10 \% \mathrm{CPH}$. This increase is associated with clay acting as toughening agent and lowering the rate of molecular mobility of the polymer chains [78], while also enhancing stress transfer from reinforcement to matrix due to improved interfacial adhesion strength between the fibre reinforcement and matrix [38]. This also means there was an increase in the energy storage ability of the composites and agrees with the elastic modulus graph in Figure 3c. Further increase in the $\mathrm{CPH}$ weight fraction shows gradual decrease in the $\mathrm{E}^{\prime}$ value with sample E2 having the lowest value of $1162.37 \mathrm{MPa}$. This is because the clay content in the composite had formed clusters forming a heterogeneous mix and creating a weak bond between matrix and fibres.
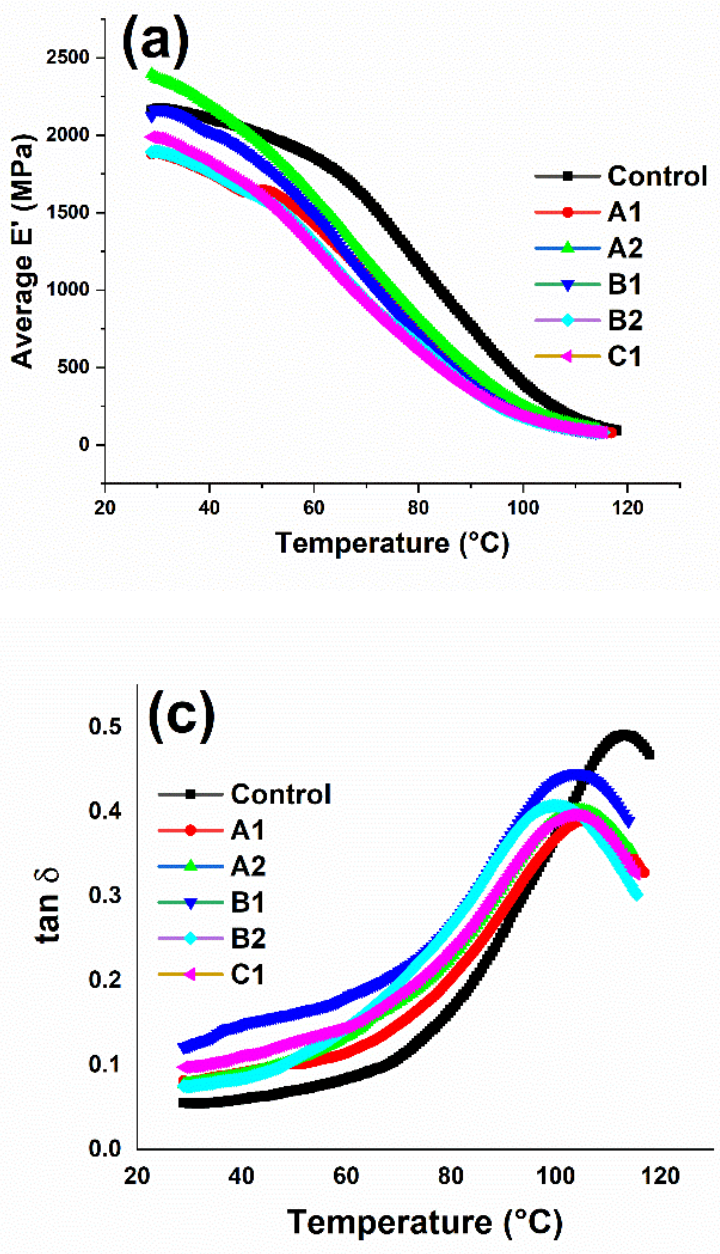
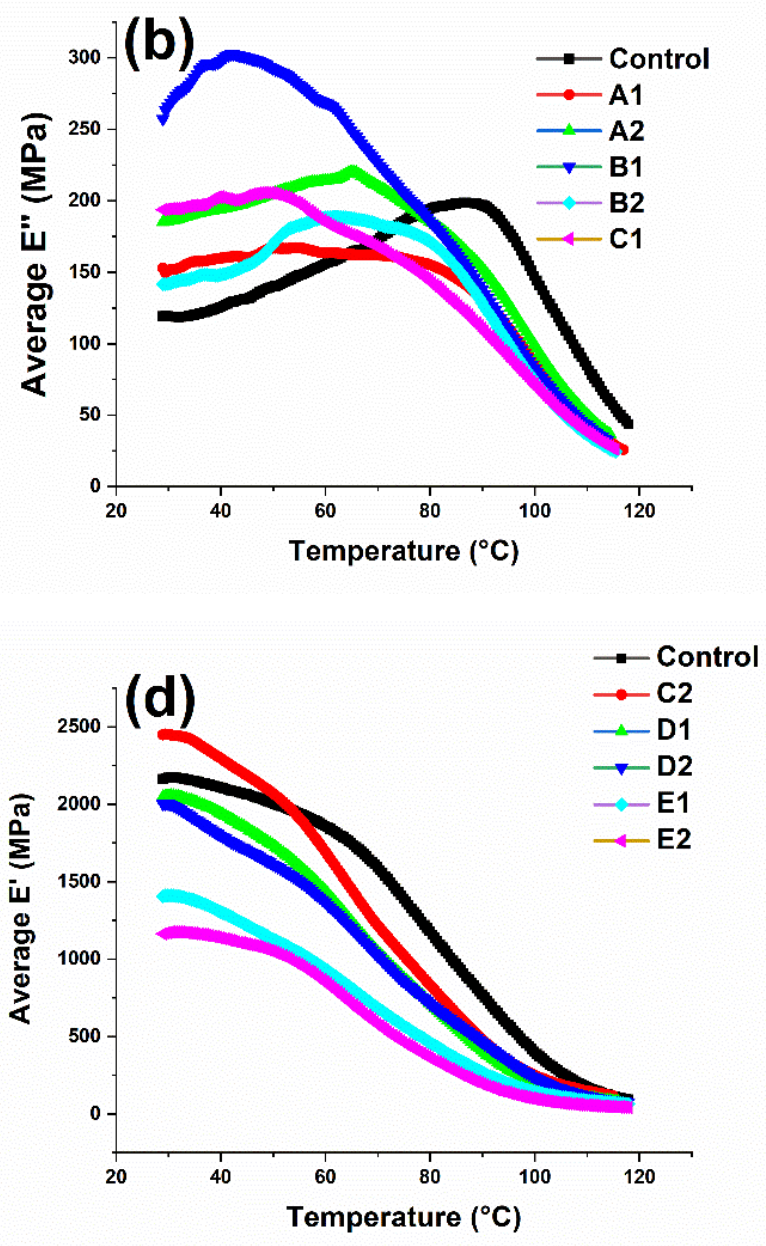

Figure 5. Cont. 

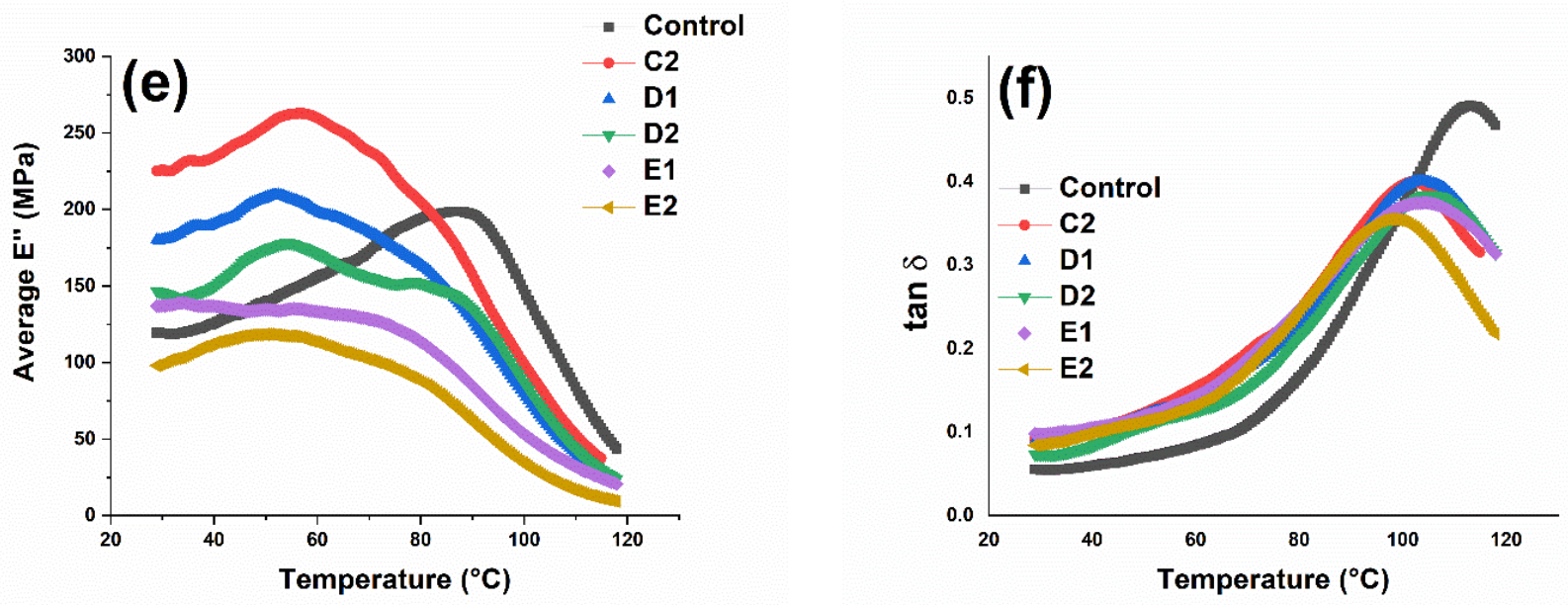

Figure 5. (a) Average storage modulus curve (E') for $\mathrm{CPH}$ reinforced composite. (b) Average loss modulus curve (E") for $\mathrm{CPH}$ reinforced composite. (c) Average damping factor tan $\delta$ for $\mathrm{CPH}$ reinforced composite. (d) Average storage modulus curve (E') for hybrid composite. (e) Average loss modulus curve ( $\left.E^{\prime \prime}\right)$ for hybrid composite. (f) Average damping factor tan $\delta$ for hybrid composite.

\subsubsection{Loss Modulus (E")}

Figure $5 \mathrm{~b}$ shows the effect of temperature on the loss modulus values of the $\mathrm{CPH}$ UPT composites. In all the cases, the loss modulus curve reached a maximum peak before decreasing at higher temperatures due to an increase in molecular mobility in the polymer chains. The UPT resin gave a broad peak in the temperature range $80-100{ }^{\circ} \mathrm{C}$ with a minimum value of loss modulus which is due to lack of heat dissipation [79] with sample B1 having the highest value. This higher value of sample B1 could be due to better adhesion between fibre and matrix. Inclusion of $\mathrm{CPH}$ fibre resulted in flatter peaks at lower temperature ranges. Similar observation has been made by [46] on Bambara nut shell polyester composite. The addition of fibre introduces greater chain segments in addition to greater loose volume and these contribute to a broadening of the loss modulus curve [80]. As the temperature increases, lignocellulosic materials begin to degrade releasing heat. This could explain the higher peak temperature of the pure UPT resin compared to the CPH composites. Loss modulus of the hybrid composite is presented in Figure $5 \mathrm{f}$ showing a decrease in $\mathrm{E}^{\prime \prime}$ with increasing fibre content with irregular glass transition temperature. This could be seen in the double peak of sample D2. However, the values obtained were higher than the UPT resin with the exception of sample E2. Such irregular behaviour was observed by Okonkwo E.G et al. and Binu P.P et al. $[46,81]$ with addition of clay to bambara nut polyester composite and inclusion of nanoclay Cloisite15A to glass fibre polyester composite. The decline in the value of E" could be due to clay agglomeration which loosens the polymeric structure [82].

\subsubsection{Damping Factor $(\tan \delta)$}

Figure $5 c$ presents the ratio of the loss modulus ( $\left.E^{\prime \prime}\right)$ and the storage modulus ( $\left.E^{\prime}\right)$ which is the mechanical loss factor or tan $\delta$. It can be related to the impact resistance of a material. The polyester (control) showed the highest $\tan \delta$ value indicative of maximum chain mobility due to poor thermal resistance of polyester resin, unlike phenolic resin, which showed a higher thermal resistance than its natural fibre reinforced composite [83]. However, introduction of $\mathrm{CPH}$ fibre shifts the curve to the left showing that fibre incorporation affects damping which could be due to the inhibition of chain mobility due to filler addition. Another reason being that the type and distribution of fibres incorporated, as well as the filler/matrix interaction and void content, all have an impact on damping 
factor [84]. As the temperature rises, the damping values reach a peak in the transition area before falling in the rubbery region.

It was observed that with the addition of clay particles, a lowering of $\tan \delta$ peaks with increase in fibre loading having sample E2 with $18 \%$ fibre content with the lowest peak. This is due to improvement in interfacial bonding as shown in Figure $5 \mathrm{f}$. The position and height of the $\tan \delta$ peak are indicators of a composite material's structure and properties [77]. Stronger interfacial adhesion means low molecular chain mobility hence less energy dissipation $[83,85]$ observed by the lowering of $\tan \delta$. Below $100{ }^{\circ} \mathrm{C}$ the fabricated composites displayed higher damping than the polyester suggesting that addition of $\mathrm{CPH} /$ clay to composites can improve their energy accumulation capabilities therefore they could be used as dampers at such temperatures.

\subsection{Statistical Optimization Results}

The results of Grey relational generation (GRG), Grey relational coefficient (GRC) and Grey relational grade (GR* grade) for the mechanical properties are shown in Tables 4 and 5 for mono-reinforced and hybrid composites, respectively, while the obtained main effects plots are presented in Figure 6. The higher grade shows that the experiment is nearer to optimum composition. Based on these results, it can be observed that multi-response optimal performance of the mono-reinforced composite can be achieved by using $82 \%$ UPT and 18\% CPH while the hybrid composites are 79\% UPT and 18\% CPH representing samples $\mathrm{C} 1$ and $\mathrm{E} 2$, respectively.

Table 4. Results of GRC and for GR*grade for mono-reinforced composites.

\begin{tabular}{cccccccc}
\hline $\begin{array}{c}\text { Run } \\
\text { Order }\end{array}$ & $\begin{array}{c}\text { GRC for } \\
\mathbf{w t} \% \text { UPT }\end{array}$ & $\begin{array}{c}\text { GRC for } \\
\text { Flexural } \\
\text { Strength } \\
\text { (MPa) }\end{array}$ & $\begin{array}{c}\text { GRC for } \\
\text { Flexural } \\
\text { Modulus } \\
\text { (GPa) }\end{array}$ & $\begin{array}{c}\text { GRC for } \\
\text { Tensile } \\
\text { Strength } \\
\text { (MPa) }\end{array}$ & $\begin{array}{c}\text { GRC for } \\
\text { Tensile } \\
\text { Modulus } \\
\text { (GPa) }\end{array}$ & $\begin{array}{c}\text { GRC for } \\
\text { Hardness } \\
\text { (HV) }\end{array}$ & $\begin{array}{c}\text { GRC for } \\
\text { GR }^{*} \text { grade }\end{array}$ \\
\hline Xo & 1.0000 & 1.0000 & 1.0000 & 1.0000 & 1.0000 & 1.0000 & - \\
A1 & 1.000 & 1.000 & 1.000 & 1.000 & 0.333 & 0.333 & 0.778 \\
A2 & 0.674 & 0.531 & 0.732 & 0.363 & 0.771 & 0.456 & 0.588 \\
B1 & 0.506 & 0.558 & 0.683 & 0.333 & 0.642 & 0.632 & 0.559 \\
B2 & 0.403 & 0.882 & 0.483 & 0.415 & 0.487 & 0.715 & 0.564 \\
C1 & 0.333 & 0.333 & 0.333 & 0.437 & 0.413 & 1.000 & 0.475 \\
\hline
\end{tabular}

Table 5. Results of GRC and for GR*grade for hybrid composites.

\begin{tabular}{cccccccc}
\hline $\begin{array}{c}\text { Run } \\
\text { Order }\end{array}$ & $\begin{array}{c}\text { GRC for } \\
\mathbf{w t} \% \text { UPT }\end{array}$ & $\begin{array}{c}\text { GRC for } \\
\text { Flexural } \\
\text { Strength } \\
\text { (MPa) }\end{array}$ & $\begin{array}{c}\text { GRC for } \\
\text { Flexural } \\
\text { Modulus } \\
\text { (GPa) }\end{array}$ & $\begin{array}{c}\text { GRC for } \\
\text { Tensile } \\
\text { Strength } \\
\text { (MPa) }\end{array}$ & $\begin{array}{c}\text { GRC for } \\
\text { Tensile } \\
\text { Modulus } \\
\text { (GPa) }\end{array}$ & $\begin{array}{c}\text { GRC for } \\
\text { Hardness } \\
\text { (HV) }\end{array}$ & $\begin{array}{c}\text { GRC for } \\
\text { GR*grade }\end{array}$ \\
\hline Xo & 1.0000 & 1.0000 & 1.0000 & 1.0000 & 1.0000 & 1.0000 & - \\
C2 & 1.000 & 1.000 & 1.000 & 1.000 & 1.000 & 0.333 & 0.889 \\
D1 & 0.675 & 0.948 & 0.756 & 0.698 & 0.753 & 0.456 & 0.714 \\
D2 & 0.506 & 0.539 & 0.653 & 0.532 & 0.763 & 0.632 & 0.604 \\
E1 & 0.403 & 0.401 & 0.603 & 0.349 & 0.503 & 0.715 & 0.496 \\
E2 & 0.333 & 0.333 & 0.333 & 0.333 & 0.333 & 1.000 & 0.444 \\
\hline
\end{tabular}



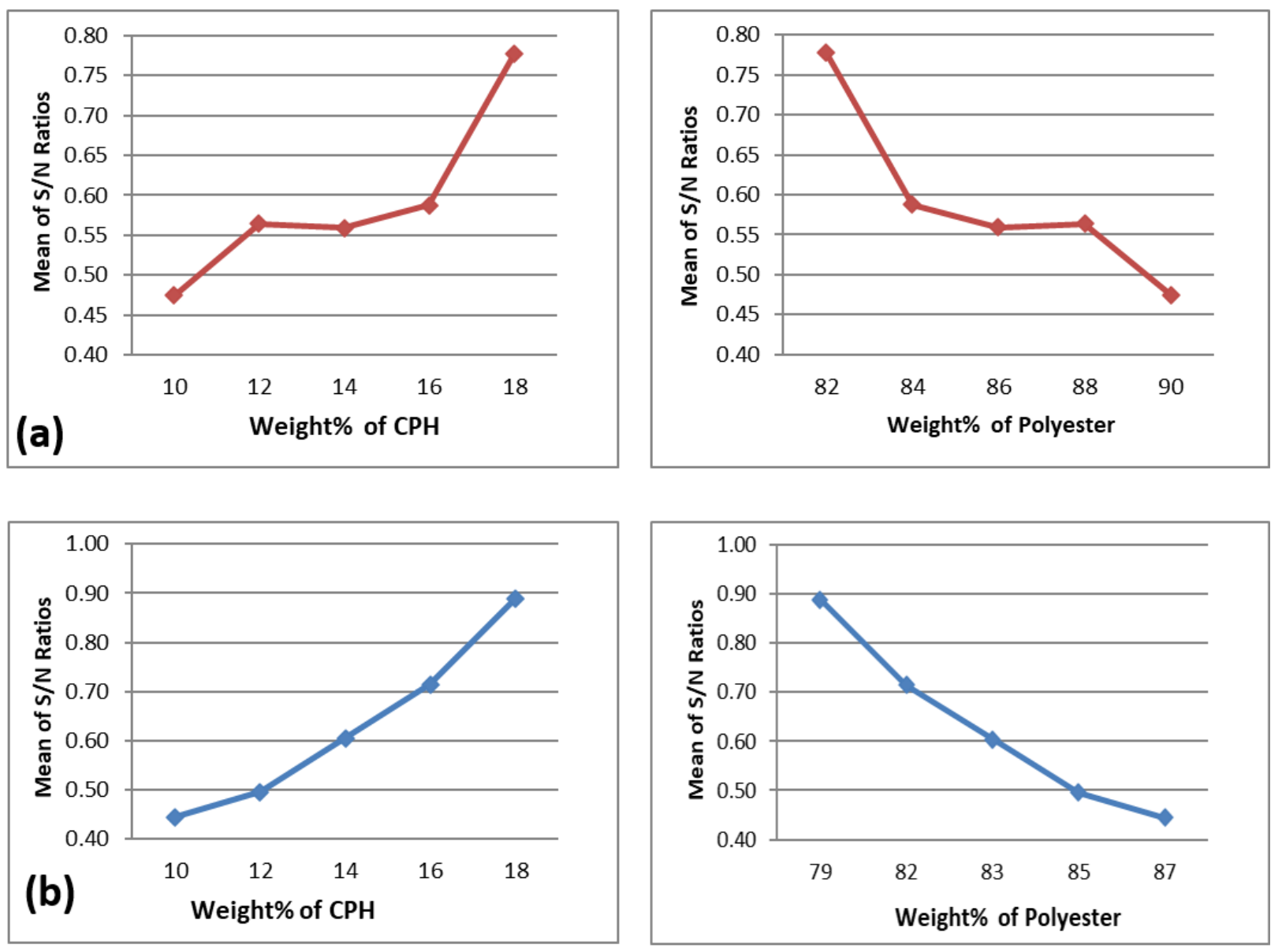

Figure 6. Main effect plot of optimal level conditions of factors for (a) mono-reinforced composite (b) hybrid composite.

\section{Conclusions}

Biomass is a viable renewable and sustainable source of raw material for diverse application and mostly used in the energy industry. In this regard, this study investigates the potentials of cowpea husk, a biomass as reinforcement for polyester as well as the influence of $3 \%$ clay addition as a secondary material on the mechanical properties. The effect of clay addition on the mechanical and thermo-mechanical behaviour of formulated composites was investigated for possible application in roofing tiles. The morphological analysis of the mono and hybrid system shows a rough and coarse inhomogeneous surface with voids created due to the addition of $\mathrm{CPH}$ filler for the mono reinforced and clay uniformly filling the voids that were created by the $\mathrm{CPH}$ in the hybrid composite. Observations made from the mechanical and thermo-mechanical properties of the composite indicates that variations in composition have an impact on the attributes of all the produced composite as they all yielded different results. The addition of cowpea husk improved hardness, tensile modulus and flexural modulus but decreased tensile strength and flexural strength. The visco-elastic test also showed improvement in the damping properties of the hybrid composite below $100{ }^{\circ} \mathrm{C}$. From the Grey relational analysis, the optimal composition for both mono-reinforced and hybrid composite is 18 percent $\mathrm{CPH}$. This proves the potential of the composite to be used in building application and also serves as a benchmark for future work. Finally, this study has provided data and knowledge to fill the missing gap of using $\mathrm{CPH}$, UPT and clay as a potential and sustainable source of raw material for building application in particular roof tiles. However, further studies on the full optimization of cowpea husk and clay should be carried out to elucidate the exact amount of cowpea husk and clay for maximum tensile and flexural strength. 


\begin{abstract}
Author Contributions: E.N.A.-F.: Conceptualization, Methodology, Writing-original draft preparation, Software, Data curation, Resources; P.A.U.: Visualization, Resources, Investigation; I.I.O.: Investigation, formal analysis; G.M.K.-U.: Visualization, Resources, Investigation; A.B.: Formal analysis, Writing-review and editing; M.I.O.: Writing-review and editing; A.O.O.: Writing-review and editing; A.P.O.: Supervision and funding acquisition. All authors have read and agreed to the published version of the manuscript.
\end{abstract}

Funding: This work was funded by the Pan African Materials Institute (PAMI), a regional Center of Excellence in Materials Science and Engineering in West Africa established under the World Bank (WB) African Centers of Excellence (ACE) program, and hosted by the African University of Science and Technology, Abuja, Nigeria. The grant number is AUST/PAMI/2015/5415-NG.

Conflicts of Interest: The authors declare that they have no known competing financial interests or personal relationships that could have appeared to influence the work reported in this paper.

\title{
References
}

1. World Health Organization. WHO Housing and Health Guidelines. 2018. Available online: http://www.who.int/phe\%0Ahttp: / / apps.who.int/bookorders (accessed on 18 June 2021).

2. Adenikinju, A.F. Bridging Housing Deficit in Nigeria: Lessons from Other Jurisdictions. Econ. Financ. Rev. 2019, 57, 17-36.

3. Moorev, R.; Moore, E.A. Addressing Housing Deficit in Nigeria: Issues, Challenges and Prospects. CBN Econ. Financ. Rev. 2019, 57, 201-222. Available online: https:/ / dc.cbn.gov.ng/efr/vol57/iss4/15/ (accessed on 18 June 2021).

4. Reckford, T.M.J. 5 Ways to Tackle the Housing Crisis after COVID-19. 2020. Available online: https://www.weforum.org/ agenda/2020/11/5-ways-to-tackle-the-housing-crisis-after-covid-19/ (accessed on 23 June 2021).

5. Mcclelland, A.; Boyle, M.; Jarvis, S.; Arnold, T. Responding to COVID-19 in the Liverpool City Region: Introducing the Heseltine Institute's COVID-19 Policy Briefs; University of Liverpool, Heseltine Institute for Public Policy, Practice and Place: Liverpool, UK, 2020; 8p. [CrossRef]

6. Olugbenga, T.D.; Yusoff, N.; Aziz, N.A.; Baba, A.N. Unleashing the Potentials of Housing Sector in Nigeria as Perceived by Users. Int. J. Built Environ. Sustain. 2017, 4, 172-179. [CrossRef]

7. Ayedun, C.A.; Oluwatobi, A.O. Issues and Challenges Militating against the Sustainability of Affordable Housing Provision in Nigeria. Bus. Manag. Dyn. 2011, 1, 1-8.

8. Mahamat, A.A.; Obianyo, I.I.; Ngayakamo, B.; Bih, N.L.; Ayeni, O.; Azeko, S.T.; Savastano, H. Alkali activation of compacted termite mound soil for eco-friendly construction materials. Heliyon 2021, 7, e06597. [CrossRef]

9. Obianyo, I.I.; Mahamat, A.A.; Anosike-Francis, E.N.; Stanislas, T.T.; Geng, Y.; Onyelowe, K.C.; Odusanya, S.; Onwualu, A.P.; Soboyejo, A.B.O.; Obianyo, I. Performance of lateritic soil stabilized with combination of bone and palm bunch ash for sustainable building applications. Cogent Eng. 2011, 8, 1921673. [CrossRef]

10. Ojo, E.B.; Mustapha, K.; Teixeira, R.S.; Savastano, H. Development of unfired earthen building materials using muscovite rich soils and alkali activators. Case Stud. Constr. Mater. 2019, 11, e00262. [CrossRef]

11. Viel, M.; Collet, F.; Lanos, C. Chemical and multi-physical characterization of agro-resources' by-product as a possible raw building material. Ind. Crops Prod. 2018, 120, 214-237. [CrossRef]

12. Jannat, N.; Hussien, A.; Abdullah, B.; Cotgrave, A. Application of agro and non-agro waste materials for unfired earth blocks construction: A review. Constr. Build. Mater. 2020, 254, 119346. [CrossRef]

13. Stanislas, T.T.; Komadja, G.C.; Ngasoh, O.F.; Obianyo, I.I.; Tendo, J.F.; Onwualu, P.A.; Junior, H.S. Performance and Durability of Cellulose Pulp-Reinforced Extruded Earth-based Composites. Arab. J. Sci. Eng. 2021, 46, 11153-11164. [CrossRef]

14. Ngayakamo, B.H.; Bello, A.; Onwualu, A.P. Development of eco-friendly fired clay bricks incorporated with granite and eggshell wastes. Environ. Chall. 2020, 1, 100006. [CrossRef]

15. Zhang, Y.; Pu, S.; Li, R.Y.M.; Zhang, J. Microscopic and mechanical properties of undistributed and remoulded red clay from Guiyang, China. Sci. Rep. 2020, 10, 18003. [CrossRef]

16. Solis, M.; Silveira, S. Technologies for chemical recycling of household plastics-A technical review and TRL assessment. Waste Manag. 2020, 105, 128-138. [CrossRef]

17. Economy, C. National Agreement on the Circular Economy. Government of The Netherlands; 2017. Available online: https:// www.government.nl/documents/discussion-documents/2017/01/24/national-agreement-on-the-circular-economy (accessed on 2 July 2021).

18. Azambuja, R.D.R.; de Castro, V.G.; Trianoski, R.; Iwakiri, S. Utilization of construction and demolition waste for particleboard production. J. Build. Eng. 2018, 20, 488-492. [CrossRef]

19. Almeshal, I.; Tayeh, B.A.; Alyousef, R.; Alabduljabbar, H.; Mohamed, A.M.; Alaskar, A. Use of recycled plastic as fine aggregate in cementitious composites: A review. Constr. Build. Mater. 2020, 253, 119146. [CrossRef]

20. Amziane, S. Overview on biobased building material made with plant aggregate. Sustain. Constr. Mater. Technol. 2016, 1, 31-38. [CrossRef] 
21. Olorunnisola, A.O. Development of Sustainable Building Materials from Agro-Industrial Wastes in Nigeria. Sustain. Constr. Build. Mater. 2019, 55-74. [CrossRef]

22. Chen, J.; Li, C.; Ristovski, Z.; Milic, A.; Gu, Y.; Islam, M.S.; Wang, S.; Hao, J.; Zhang, H.; He, C.; et al. A review of biomass burning: Emissions and impacts on air quality, health and climate in China. Sci. Total Environ. 2017, 579, 1000-1034. [CrossRef] [PubMed]

23. Kumar, P.; Joshi, L. Pollution Caused by Agricultural Waste Burning and Possible Alternate Uses of Crop Stubble: A Case Study of Punjab. Wasser Abfall 2019, 21, 51. [CrossRef]

24. Yahaya, F. The Menace of Soot in Portharcourt. Indep. Newspapers Ltd. 2018. Available online: https://independent.ng/themenace-of-soot-in-port-harcourt/ (accessed on 26 September 2021).

25. Rees, N.; Wickham, A.; Choi, Y. Silent Suffocation in Africa: Air Pollution Is a Growing Menace, Affacting the Poorest Children the Most; United Nations Children's Fund (UNICEF): New York, NY, USA, 2019; pp. 1-14. Available online: https://www.unicef.org/ media/55081/file/Silent_suffocation_in_africa_air_pollution_2019.pdf (accessed on 26 September 2021).

26. Guna, V.; Yadav, C.; Maithri, B.R.; Ilangovan, M.; Touchaleaume, F.; Saulnier, B.; Grohens, Y.; Reddy, N. Wool and coir fiber reinforced gypsum ceiling tiles with enhanced stability and acoustic and thermal resistance. J. Build. Eng. 2021, $41,102433$. [CrossRef]

27. Akindapo, J.O.; Binni, U.A.; Sanusi, O.M. Development of Roofing Sheet Material Using Groundnut Shell Particles and Epoxy Resin as Composite Material. Am. J. Eng. Res. 2015, 4, 165-173.

28. De Vecchi, A.; Valenza, A.; Colajanni, S.; Sanfilippo, E.; Fiore, V.; Volpe, A.L. Evaluation and application of opuntia ficus-indica panel. Acad. J. Civ. Eng. 2015, 33, 460-466. [CrossRef]

29. Darsana, P.; Abraham, R.; Joseph, A.; Jasheela, A.; Binuraj, P.R.; Sarma, J. Development of Coir-fibre Cement Composite Roofing Tiles. Procedia Technol. 2016, 24, 169-178. [CrossRef]

30. Pasilo, A.; Teeboonma, U. A Study of the Roofing Tiles Product Properties Manufactured from Agricultural Residues. In Proceedings of the 2018 International Conference and Utility Exhibition on Green Energy for Sustainable Development (ICUE), Phuket, Thailand, 24 October 2018; pp. 713-722. [CrossRef]

31. Topacio, A.; Eng, M.; Arkuino, R.C.; Romano, K.V.; Jayvee, C. Development of Hydrophobic Composite Roof Tiles Utilizing Recycled Plastic Materials. Mater. Eng. Dev. 2018, 6, 1-3.

32. Okafor, C.E.; Ihueze, C.C. Strength Analysis and Variation of Elastic Properties in Plantain Fiber/Polyester Composites for Structural Applications. In Composite and Nanocomposite Materials_From Knowledge to Industrial Applications; IntechOpen: London, UK, 2020; pp. 1-23. [CrossRef]

33. Beaumont, P.W.; Soutis, C.; Hodzic, A. The Structural Integrity of Carbon Fiber Composites, 1st ed.; Springer: Cham, Switzerland, 2017. [CrossRef]

34. Pei, X.; Han, W.; Ding, G.; Wang, M.; Tang, Y. Temperature effects on structural integrity of fiber-reinforced polymer matrix composites: A review. J. Appl. Polym. Sci. 2019, 136, 48206. [CrossRef]

35. Atiqah, A.; Maleque, M.A.; Jawaid, M.; Iqbal, M. Development of kenaf-glass reinforced unsaturated polyester hybrid composite for structural applications. Compos. Part B Eng. 2014, 56, 68-73. [CrossRef]

36. Saba, N.; Jawaid, M.; Alothman, O.Y.; Paridah, M.T. A review on dynamic mechanical properties of natural fibre reinforced polymer composites. Constr. Build. Mater. 2016, 106, 149-159. [CrossRef]

37. Adeosun, S.O.; Akpan, E.I.; Akanegbu, H.A. Thermo-Mechanical Properties of Unsaturated Polyester Reinforced with Coconut and Snail Shells. Int. J. Compos. Mater. 2015, 5, 52-64. [CrossRef]

38. Chee, S.S.; Jawaid, M.; Alothman, O.Y.; Fouad, H. Effects of nanoclay on mechanical and dynamic mechanical properties of bamboo/kenaf reinforced epoxy hybrid composites. Polymers 2021, 13, 395. [CrossRef]

39. Hansen, B.; Borsoi, C.; Júnior, M.A.D.; Catto, A.L. Thermal and thermo-mechanical properties of polypropylene composites using yerba mate residues as reinforcing filler. Ind. Crops Prod. 2019, 140, 111696. [CrossRef]

40. Lalit, R.; Mayank, P.; Ankur, K. Natural fibers and biopolymers characterization: A future potential composite material. J. Mech Eng. 2018, 68, 33-50. [CrossRef]

41. Yıldızhan, S.; Çalık, A.; Özcanlı, M.; Serin, H. Bio-composite materials: A short review of recent trends, mechanical and chemical properties, and applications. Eur. Mech. Sci. 2018, 2, 83-91. [CrossRef]

42. Hills, C.D.; Tripathi, N.; Singh, R.S.; Carey, P.J.; Lowry, F. Valorisation of agricultural biomass-ash with $\mathrm{CO}_{2}$. Sci. Rep. 2020, 10, 13801. [CrossRef] [PubMed]

43. Dhaliwal, J.S. "Natural Fibers: Applications." Generation, Development and Modifications of Natural Fiber; Intech: Vienna, Austria, 2019; pp. 1-23. [CrossRef]

44. Arulmurugan, S.; Venkateshwaran, N. Effect of nanoclay addition and chemical treatment on static and dynamic mechanical analysis of jute fibre composites. Polimeros 2019, 29, 4-11. [CrossRef]

45. Hossen, M.F.; Hamdan, S.; Rahman, M.R.; Rahman, M.M.; Liew, F.K.; Lai, J.C. Effect of fiber treatment and nanoclay on the tensile properties of jute fiber reinforced polyethylene/clay nanocomposites. Fibers Polym. 2015, 16, 479-485. [CrossRef]

46. Okonkwo, E.G.; Anabaraonye, C.N.; Egoigwe, S.V.; Okeke, P.E.; Whyte, F.G. Mechanical and thermomechanical properties of clay-Bambara nut shell polyester bio-composite. Int. J. Adv. Manuf. Technol. 2020, 108, 2483-2496. [CrossRef]

47. Aderogba, K.A. Polymer Wastes and Management in Cities and Towns of Africa and Sustainable Environment: Nigeria and European Experiences. Soc. Sci. 2014, 3, 79. [CrossRef] 
48. Gao, Y.; Romero, P.; Zhang, H.; Huang, M.; Lai, F. Unsaturated polyester resin concrete: A review. Constr. Build. Mater. 2019, 228, 116709. [CrossRef]

49. ASTM D3039; Standard Test Method for Tensile Properties of Polymer Matrix Composite Materials. ASTM International: West Conshohocken, PA, USA, 2017. [CrossRef]

50. ASTM D790; Standard Test Methods for Flexural Properties of Unreinforced and Reinforced Plastics and Electrical Insulating Materials. American Society for Testing and Materials: Philadelphia, PA, USA, 2010.

51. Saba, N.; Jawaid, M.; Sultan, M.T.H. An Overview of Mechanical and Physical Testing of Composite Materials; Woodhead Publishing: Cambridge, UK, 2018. [CrossRef]

52. ASTM D5023-15; Standard Test Method for Plastics: Dynamic Mechanical Properties: In Flexure (Three-Point Bending). ASTM International: West Conshohocken, PA, USA, 2015. Available online: https:/ / www.astm.org/(accessed on 15 April 2021).

53. Liu, S.; Lin, Y. Introduction to grey systems theory. J. Grey Syst. 1989, 1, 1-24. [CrossRef]

54. Morán, J.; Granada, E.; Míguez, J.L.; Porteiro, J. Use of grey relational analysis to assess and optimize small biomass boilers. Fuel Process. Technol. 2006, 87, 123-127. [CrossRef]

55. Kuo, Y.; Yang, T.; Huang, G.W. The use of a grey-based Taguchi method for optimizing multi-response simulation problems. Eng. Optim. 2008, 40, 517-528. [CrossRef]

56. Abutu, J.; Lawal, S.A.; Ndaliman, M.B.; Lafia-Araga, R.A.; Adedipe, O.; Choudhury, I.A. Effects of process parameters on the properties of brake pad developed from seashell as reinforcement material using grey relational analysis. Eng. Sci. Technol. Int. J. 2018, 21, 787-797. [CrossRef]

57. Mourad, A.H.I.; Abu-Jdayil, B.; Hassan, M. Mechanical behavior of Emirati red shale fillers/unsaturated polyester composite. SN Appl. Sci. 2020, 2, 497. [CrossRef]

58. Halim, Z.A.A.; Yajid, M.A.M.; Idris, M.H.; Hamdan, H. Effects of silica aerogel particle sizes on the thermal-mechanical properties of silica aerogel-unsaturated polyester composites. Plast. Rubber Compos. 2017, 46, 184-192. [CrossRef]

59. Adi, M.; Abu-jdayil, B.; al Ghaferi, F.; al Yahyaee, S.; al Jabri, M. Seawater-Neutralized Bauxite Residue-Polyester Composites as Insulating Construction Materials. Buildings 2021, 11, 20. [CrossRef]

60. Abu-Jdayil, B.; Mourad, A.H.I.; Hussain, A. Investigation on the mechanical behavior of polyester-scrap tire composites. Constr. Build. Mater. 2016, 127, 896-903. [CrossRef]

61. Abral, H.; Andriyanto, H.; Samera, R.; Sapuan, S.M.; Ishak, M.R. Mechanical Properties of Screw Pine (Pandanus Odoratissimus) Fibers-Unsaturated Polyester Composites. Polym.-Plast. Technol. Eng. 2012, 51, 500-506. [CrossRef]

62. Reddy, K.O.; Shukla, M.; Maheswari, C.U.; Rajulu, A.V. Evaluation of mechanical behavior of chemically modified Borassus fruit short fiber/unsaturated polyester composites. J. Compos. Mater. 2012, 46, 2987-2998. [CrossRef]

63. Fan, Y.; Lou, J.; Shinozaki, D.M. Microstructure dependent properties of polypropylene-clay nanocomposites. J. Appl. Polym. Sci. 2007, 103, 204-210. [CrossRef]

64. Norizan, M.N.; Abdan, K.; Salit, M.S.; Mohamed, R. Physical, mechanical and thermal properties of sugar palm yarn fibre loading on reinforced unsaturated polyester composites. J. Phys. Sci. 2017, 28, 115-136. [CrossRef]

65. del Pino, G.G.; Kieling, A.C.; Bezazi, A.; Boumediri, H.; de Souza, J.F.R.; Díaz, F.V.; Rivera, J.L.V.; Dehaini, J.; Panzera, T.H. Hybrid Polyester Composites Reinforced with Curauá Fibres and Nanoclays. Fibers Polym. 2020, 21, 399-406. [CrossRef]

66. Shahroze, R.M.; Ishak, M.R.; Salit, M.S.; Leman, Z.; Asim, M.; Chandrasekar, M. Effect of organo-modified nanoclay on the mechanical properties of sugar palm fiber-reinforced polyester composites. BioResources 2018, 13, 7430-7444. [CrossRef]

67. Reddy, T.R.K.; Kim, H.-J.; Park, J.-W. Renewable Biocomposite Properties and their Applications. In Composites from Renewable and Sustainable Materials; IntechOpen: London, UK, 2016; pp. 177-197. [CrossRef]

68. Ali, M.F.; Hossain, M.S.; Moin, T.S.; Ahmed, S.; Chowdhury, A.M.S. Utilization of waste chicken feather for the preparation of eco-friendly and sustainable composite. Clean. Eng. Technol. 2021, 4, 100190. [CrossRef]

69. Naveen, J.; Jawaid, M.; Zainudin, E.S.; Sultan, M.T.H.; Yahaya, R. Improved mechanical and moisture-resistant properties of woven hybrid epoxy composites by graphene nanoplatelets (GNP). Materials 2019, 12, 1249. [CrossRef]

70. Medupin, R.O.; Abubakre, O.K.; Abdulkareem, A.S.; Muriana, R.A.; Kariim, I.; Bada, S.O. Thermal and physico-mechanical stability of recycled high density polyethylene reinforced with oil palm fibres. Eng. Sci. Technol. Int. J. 2017, 20, 1623-1631. [CrossRef]

71. Kaymakci, A.; Ayrilmis, N. Composites: Part B Investigation of correlation between Brinell hardness and tensile strength of wood plastic composites. Compos. Part B 2014, 58, 582-585. [CrossRef]

72. Kumar, S.S. Dataset on mechanical properties of natural fiber reinforced polyester composites for engineering applications. Data Br. 2020, 28, 105054. [CrossRef] [PubMed]

73. Ala, E.S.W. Preparation of Polymeric Composites from Saturated Polyesters Glass Powder (Flourscent) and Study of its Mechanical Properties. Iraqi J. Mark. Res. Consum. Prot. 2021, 13, 131-139. [CrossRef]

74. Kaymakci, A.; Ayrilmis, N.; Gulec, T. Surface properties and hardness of polypropylene composites filled with sunflower stalk flour. BioResources 2013, 8, 592-602. [CrossRef]

75. Wypych, G. The Effect of Fillers on the Mechanical Properties of Filled Materials. In Handbook of Fillers, 4th ed.; Elsevier: Amsterdam, The Netherlands, 2016; pp. 467-531. [CrossRef]

76. Kaundal, R. Utilization of Flyash as Filler Material in Hybrid Polyester Composites for Improved Thermo-Mechanical and Erosion Wear Behavior. Silicon 2018, 10, 2439-2452. [CrossRef] 
77. Palanivel, A.; Veerabathiran, A.; Duruvasalu, R.; Iyyanar, S.; Velumayil, R. Dynamic mechanical analysis and crystalline analysis of hemp fiber reinforced cellulose filled epoxy composite. Polimeros 2017, 27, 309-319. [CrossRef]

78. Saba, N.; Safwan, A.; Sanyang, M.L.; Mohammad, F.; Pervaiz, M.; Jawaid, M.; Alothman, O.Y.; Sain, M. Thermal and dynamic mechanical properties of cellulose nanofibers reinforced epoxy composites. Int. J. Biol. Macromol. 2017, 102, 822-828. [CrossRef]

79. Sreenivasan, V.S.; Rajini, N.; Alavudeen, A.; Arumugaprabu, V. Dynamic mechanical and thermo-gravimetric analysis of Sansevieria cylindrica/polyester composite: Effect of fiber length, fiber loading and chemical treatment. Compos. Part B Eng. 2015, 69, 76-86. [CrossRef]

80. Pothan, L.A.; Thomas, S.; Groeninckx, G. The role of fibre/matrix interactions on the dynamic mechanical properties of chemically modified banana fibre/polyester composites. Compos. Part A Appl. Sci. Manuf. 2006, 37, 1260-1269. [CrossRef]

81. Binu, P.P.; George, K.E.; Vinodkumar, M.N. Effect of Nanoclay, Cloisite15A on the Mechanical Properties and Thermal Behavior of Glass Fiber Reinforced Polyester. Procedia Technol. 2016, 25, 846-853. [CrossRef]

82. Jesuarockiam, N.; Jawaid, M.; Zainudin, E.S.; Sultan, M.T.H.; Yahaya, R. Enhanced thermal and dynamic mechanical properties of synthetic/natural hybrid composites with graphene nanoplateletes. Polymers 2019, 11, 1085. [CrossRef]

83. Asim, M.; Jawaid, M.; Paridah, M.T.; Saba, N.; Nasir, M.; Shahroze, R.M. Dynamic and thermo-mechanical properties of hybridized kenaf/PALF reinforced phenolic composites. Polym. Compos. 2019, 40, 3814-3822. [CrossRef]

84. Mallarino, S.; Chailan, J.F.; Vernet, J.L. Interphase study in cyanate/glass fibre composites using thermomechanical analysis and micro-thermal analysis. Compos. Sci. Technol. 2009, 69, 28-32. [CrossRef]

85. Lazar, P.J.L.; Sengottuvelu, R.; Natarajan, E. Assessments of secondary reinforcement of epoxy matrix-glass fibre composite laminates through nanosilica $\left(\mathrm{SiO}_{2}\right)$. Materials 2018, 11, 2186. [CrossRef] [PubMed] 